University of Windsor

Scholarship at UWindsor

Jun 3rd, 9:00 AM - Jun 6th, 5:00 PM

\title{
In Varietate Concordia-United in Diversity: European \\ Parliamentary debate as an argumentative activity type
}

Frans $\mathrm{H}$. Van Eemeren

University of Amsterdam

Bart Garssen

University of Amsterdam

Follow this and additional works at: https://scholar.uwindsor.ca/ossaarchive

Part of the Philosophy Commons

Van Eemeren, Frans H. and Garssen, Bart, "In Varietate Concordia-United in Diversity: European Parliamentary debate as an argumentative activity type" (2009). OSSA Conference Archive. 39. https://scholar.uwindsor.ca/ossaarchive/OSSA8/papersandcommentaries/39

This Paper is brought to you for free and open access by the Conferences and Conference Proceedings at Scholarship at UWindsor. It has been accepted for inclusion in OSSA Conference Archive by an authorized conference organizer of Scholarship at UWindsor. For more information, please contact scholarship@uwindsor.ca. 


\title{
In Varietate Concordia-United in Diversity: European Parliamentary debate as an argumentative activity type
}

\section{FRANS H. VAN EEMEREN and BART GARSSEN}

\author{
Department of Speech Communication, Argumentation Theory and Rhetoric \\ University of Amsterdam \\ Spuistraat 134 \\ 1012 VB Amsterdam \\ The Netherlands \\ f.h.vaneemeren@uva.nl \\ b.j.garssen@uva.nl
}

\begin{abstract}
This paper focuses on argumentation in a specific institutional context: debate in the European Parliament. A parliamentary debate is a distinct argumentative activity type. In the pragmadialectical approach, argumentative activity types are defined as conventionalized argumentative practices in which the possibilities for strategic manoeuvring are predetermined. What are the characteristics of the activity type of a debate in European Parliament that predetermine the possibilities for strategic manoeuvring? What kind of constraints and opportunities for strategic manoeuvring can be distinguished?
\end{abstract}

KEYWORDS: argumentative activity types, political argumentation, strategic manoeuvring

\section{INTRODUCTION}

In Varietate Concordia - United in Diversity, the motto of the European Union printed proudly on all official paperwork of the European Parliament, proves a smart choice now so many Europeans are ambivalent about the European project. On the one hand the Europeans are afraid that they will lose control over their own national identities as a consequence of the rapidly increasing power of Europe's central administration; on the other hand they realize that the European Union brings more prosperity and makes it possible to fight the financial and economic crisis much more effectively. The motto voices this ambivalence and points to the predicament of the European Parliament: having to reconcile a quest for univocal common legislation that serves the whole Union with satisfying a variety of different local interests and views. Over the years, the European Parliament has become an institution with a certain amount of power, especially since the co-decision procedure has come into place that gives the European Parliament the right to decide together with the European Council on new legislation initiated by the European Commission.

In our contribution to this special issue on strategic manoeuvring in political discourse we want to shed some light on how European legislation and policies are debated in European Parliament and how strategic manoeuvring in European

Eemeren, F. H. van and B. Garssen (2009). In Varietate Condordia-United in Diversity: European Parliamentary debate as an argumentative activity type. In: J. Ritola (Ed.), Argument Cultures: Proceedings of OSSA 09, CD-ROM (pp. 1-15), Windsor, ON: OSSA.

Copyright (C) 2009, the author. 
parliamentary debate is preconditioned by the specific conventionalization of this debate and the participants' dualistic position regarding Europe and their home countries. We shall try to do so by characterizing plenary European parliamentary debate as an argumentative activity type which affects the conduct of political argumentative discourse. In taking the pragma-dialectical approach to strategic manoeuvring in political argumentative discourse, we join in with the other studies of the political domain brought together in this issue, while contributing at the same time to the exploration of argumentative discourse in European Parliament, our new research focus.

\section{CONVENTIONALIZED COMMUNICATIVE PRACTICES AS} ARGUMENTATIVE ACTIVITY TYPES

Argumentation is a theoretical concept given shape in analytical models such as the ideal model of a critical discussion but it is also, and even in the first place, an empirical phenomenon that can be observed in a multitude of communicative practices. Because these communicative practices are connected with specific kinds of institutional contexts in which they serve a variety of institutionally relevant purposes, they have become conventionalized in accordance with varying kinds of requirements. ${ }^{1}$ Due to the contextdependency of communicative practices, the possibilities for strategic manoeuvring in argumentative discourse taking place in such practices are to some extent determined by the institutional preconditions prevailing in the communicative practice concerned. This makes it necessary to situate the analysis and evaluation of strategic manoeuvring in the macro-context of the "communicative activity type" in which the manoeuvring occurs (van Eemeren \& Houtlosser 2005).

Characterizing the macro-context of a communicative activity type amounts to describing, starting from the domain of communicative activity to which a certain communicative practice belongs, the institutional conventions instrumental in realizing through a particular kind ("genre") of communicative activity the "institutional point" of the communicative practice. ${ }^{2}$ Assuming that the conventionalization of communicative activity types has come into being to serve the purpose of realizing the institutional point of the communicative practices concerned, the conventionalization of every communicative practice that can be intersubjectively recognized as such may be deemed dependent on the institutional rationale of this communicative practice. ${ }^{3}$ Such an

\footnotetext{
${ }^{1}$ We use the terms institution, institutional and institutionalized in a very broad sense, so that they refer to any established macro-context in which certain communicative conventions have developed.

${ }^{2}$ This concept of activity types introduced by van Eemeren and Houtlosser (2005) will be explained in more detail in van Eemeren (to be published). Levinson uses the term activity type in the meaning of "fuzzy category whose focal members are goal-defined, socially constituted, bounded, events with constraints on participants, setting, and so on, but above all on the kinds of allowable contributions" (1992, p. 69).

${ }^{3}$ We think that our approach connects with "rational choice institutionalism" within New Institutionalism as practiced in political science, economics, anthropology and sociology. In dealing with the question of how to construe the relationship between institutions and behavior, new institutionalism emphasizes the relative autonomy of political institutions and the importance of symbolic action to understanding institutionalized behavior (March \& Olsen, 1984, p. 734). According to Hall and Taylor, rational choice institutionalism draws our attention to "the role that strategic interaction between actors plays in the determination of political outcomes"(1996, p. 951). Generally this approach is highly "functionalist" in the sense of explaining the origins of an institution largely in terms of the effects that follow from its existence,
} 


\section{IN VARIETATE CONCORDIA - UNITED IN DIVERSITY}

institutional rationale reflects the institutional needs the communicative practice aims to satisfy and manifests itself in the contextual succession of individual speech events issued in the domain of communicative activity in which the conventionalized communicative activity type concerned has developed. Generally, when studying these speech events from the perspective of argumentation theory we are examining them as tokens, instantiations or representations of a communicative activity type. ${ }^{4}$

Viewed in this way, communicative activity types are conventionalized communicative practices whose conventionalization serves the institutional needs of a certain domain of communicative activity through the implementation of a specific genre of communicative activity. ${ }^{5}$ The genres of communicative activity that are employed may vary from adjudication, disputation and deliberation to negotiation, consultation and "communion-ation." 6 Realizing the institutional point of a communicative activity type through the use of the appropriate genre of communicative activity amounts to accomplishing the institutional mission this activity type is meant to fulfill in a certain communicative domain. In some cases the conventions of the communicative activity types making use of a certain genre of communicative activity are fully explicit constitutive or regulative rules, in other cases they are largely implicit rules of some kind, established practices or simply common usage.

Among the communicative activity types that have come into being in the political domain, where the genre of deliberation is used most prominently, are next to the plenary European debate examined by us for instance also the General Debate [“algemene beschouwingen”] in Dutch Parliament, the lawmaking debate in British Parliament, Prime Minister's Question Time in British Parliament, and the political interview. ${ }^{7}$ The general institutional point that all these communicative activity types have in common on an abstract level is preserving political democracy. In the case of the

"intentionalist" in the sense of assuming that the process of institutional creation is a highly purposive one, and its analyses are highly "voluntarist" in the sense that they tend to view institutional creation as a quasicontractual process marked by voluntary agreement among relatively equal and independent actors (Hall \& Taylor, 1996, p. 952).

${ }^{4}$ In practice, we may sometimes be specifically interested in a particular individual speech event; for instance, when we are conducting a case study of a certain historical text, such as the Apologia pamphlet that William the Silent published in 1580 in response to the Ban Edict issued by King Philip II of Spain (van Eemeren \& Houtlosser 1999, 2000).

${ }^{5}$ As explained by van Eemeren and Houtlosser (2005), communicative activity types are not on a par with theoretical constructs such as the pragma-dialectical ideal model of a critical discussion. While these theoretical constructs are based on analytic considerations concerning the best way of reaching a certain (abstract) objective such as resolving a difference of opinion on the merits, the various communicative activity types are empirically-based prototypes of conventionalized communicative practices. Unlike theoretical constructs such as the model of a critical discussion, which are designs for identifying the constitutive parts of a problem-valid procedure for achieving a specific normative objective, the various communicative activity types and their associated speech events represent communicative practices that have come into being and have been conventionalized in the culturally established pursuit of realizing the institutional point of a communicative activity. By distinguishing in this way between an ideal model and argumentative activity types, and making a fundamental theoretical distinction between these two categories of concepts, we deviate in an essential way from approaches to argumentative discourse types such as Walton's (1998) and Walton and Krabbe's (1995). For a comparison between our approach and theirs, see van Eemeren, Houtlosser, Ihnen and Lewinski (to be published).

"Such genres can also be viewed as "families" or "conglomerates" of communicative activity serving certain clusters of communicative activity types.

${ }^{7}$ See also Ilie (2003) and Zarefsky (2008). 
General Debate in Dutch Parliament, for instance, the more specific institutional aim is to confront the government with the views of the elected representatives of the people on their policy plans and the financial backing of these plans; the institutional conventions of the General Debate are provided by parliamentary tradition and the debate format is laid down in parliamentary procedure. The institutional aim of Prime Minister's Question time, to give another example, is to hold the Prime Minister to account for his government's policies; the institutional conventions of Question Time and the format of the exchange of questions and answers are determined by existing regulations, the House of Commons Procedure Committee and the parliamentary rule of order. The institutional aim of a political interview, finally, is to make the politician clarify and justify his position; the institutional conventions are determined by the regulations pertaining to the medium and the professional requirements of the trade, which also determine the format. As an illustration of the relationship between communicative activity types and certain genres of communicative activity we list in figure 1 some of the disputational activity types just mentioned together with some communicative activity types implementing other genres of communicative activity.

\begin{tabular}{|l|l|l|l|}
\hline $\begin{array}{l}\text { domain } \begin{array}{l}\text { of } \\
\text { activity }\end{array} \\
\text { genre } \\
\text { communicative } \\
\text { activity }\end{array}$ & $\begin{array}{l}\text { lommunicative } \\
\text { activity } \\
\text { type }\end{array}$ & speech event \\
\hline $\begin{array}{l}\text { communication } \\
\text { communication }\end{array}$ & adjudication & $\begin{array}{l}\text { - court } \\
\text { proceedings } \\
- \text { arbitration } \\
- \text { summons }\end{array}$ & $\begin{array}{l}\text { defence pleading at } \\
\text { O.J. Simpson's } \\
\text { murder trial }\end{array}$ \\
\hline $\begin{array}{l}\text { (inter)personal } \\
\text { communication }\end{array}$ & communion-ation & $\begin{array}{l}\text { - General Debate } \\
\text { political } \\
\text { interview } \\
- \text { Prime Minister's } \\
\text { Question Time }\end{array}$ & $\begin{array}{l}\text { Geert Wilders's } \\
\text { contribution to the } \\
\text { General Debate of } \\
\text { 2008 }\end{array}$ \\
\hline
\end{tabular}

Figure 1: Examples of communicative activity types implementing genres of communicative activity

Communicative activity types may be non-argumentative, but in these activity types more often than not-directly or indirectly-argumentation plays a part, whether structurally or incidentally, so that the communicative activity type concerned is partly or wholly argumentative. Whereas a parliamentary debate is inherently argumentative, a political interview argumentative in essence, and a love letter as a rule not argumentative, a prayer 


\section{IN VARIETATE CONCORDIA - UNITED IN DIVERSITY}

may be coincidentally argumentative when it tries to claim a favour and contains perhaps even supporting arguments. When analyzing communicative activity types that are inherently or essentially argumentative we call them argumentative activity types. In argumentation research, however, the term argumentative activity type is also used when other communicative activity types are analyzed for their argumentative dimension (van Eemeren \& Houtlosser 2005).

The theoretical model of a critical discussion developed in pragma-dialectics can be instrumental in characterizing a communicative activity type as an argumentative activity type, because depending on the institutional requirements the four stages of a critical discussion are "realized" in the argumentative activity types of argumentative reality in different fashions. For each communicative activity type it must be determined in what way it can be characterized argumentatively by describing the distinctive features of the empirical counterparts of the four stages of a critical discussion: the initial situation, the procedural and material starting points, the argumentative means and criticisms and the possible outcome. In figure 2 we give in these terms a general argumentative characterization of the multi-varied communicative activity types making use of deliberation in the political domain. ${ }^{8}$

\begin{tabular}{|c|c|c|c|c|}
\hline $\begin{array}{l}\text { critical } \\
\text { discussion }\end{array}$ & $\begin{array}{l}\text { confrontation } \\
\text { stage }\end{array}$ & opening stage & $\begin{array}{l}\text { argumentation } \\
\text { stage }\end{array}$ & $\begin{array}{l}\text { concluding } \\
\text { stage }\end{array}$ \\
\hline $\begin{array}{l}\text { genre of } \\
\text { communicative } \\
\text { activity }\end{array}$ & initial situation & $\begin{array}{l}\text { procedural and } \\
\text { material } \\
\text { starting points }\end{array}$ & $\begin{array}{l}\text { argumentative } \\
\text { means and } \\
\text { criticisms }\end{array}$ & $\begin{array}{l}\text { possible } \\
\text { outcome }\end{array}$ \\
\hline deliberation & $\begin{array}{l}\text { characteristically } \\
\text { mixed or } \\
\text { exceptionally } \\
\text { non-mixed } \\
\text { disagreement on } \\
\text { policy issue; } \\
\text { decision up to a } \\
\text { usually non- } \\
\text { interactive and } \\
\text { heterogeneous } \\
\text { audience }\end{array}$ & $\begin{array}{l}\text { explicit or } \\
\text { implicit rules } \\
\text { of debate; } \\
\text { explicit and } \\
\text { implicit (pre- } \\
\text { eminently } \\
\text { value-related) } \\
\text { concessions on } \\
\text { both sides }\end{array}$ & $\begin{array}{l}\text { argumentation } \\
\text { and criticisms } \\
\text { regarding the } \\
\text { standpoints at } \\
\text { issue in critical } \\
\text { exchanges }\end{array}$ & $\begin{array}{l}\text { settlement of } \\
\text { disagreement } \\
\text { or resolution } \\
\text { for parts of the } \\
\text { audience } \\
\text { (exceptionally } \\
\text { no return to } \\
\text { initial } \\
\text { situation) }\end{array}$ \\
\hline
\end{tabular}

Figure 2: Argumentative characterization of communicative activity types exploiting the genre of deliberation

\footnotetext{
${ }^{8}$ Although some also speak of "deliberation" when there is no "third party" audience, we are inclined to think that the fact that the (assumed) presence of a third party audience is vital for the strategic maneuvering taking place in deliberation. In fact, without such an audience the institutional constraints on the strategic maneuvering will rather be those of disputation or some other genre of communicative activity.
} 


\section{INSTITUTIONAL PRECONDITIONS FOR STRATEGIC MANEUVERING}

In all communicative activity types the participants manoeuvre strategically to fulfill their institutional mission in the specific macro-context concerned in a way that is reasonable and effective at the same time. Due to the specific requirements of the institutional mission, certain modes of strategic manoeuvring may lend themselves well or, as the case may be, not so well for being used in a specific communicative activity type. The institutional preconditions stipulated by the communicative activity type in which the strategic manoeuvring takes place may affect all three aspects of strategic manoeuvring in every discussion stage: in the confrontation stage, opening stage, argumentation stage as well as concluding stage there can be constraints regarding the topical choices, the adaptation to audience demand, and the use of presentational devices which impose, on the one hand, specific limitations on the possibilities for strategic manoeuvring and create, on the other hand, specific opportunities for strategic manoeuvring.

Communicative activity types implementing deliberation start as a rule from a mixed or exceptionally non-mixed disagreement on a policy issue between two or more persons who are addressing each other or are responding to each other's contributions but are in fact out to gain the support of a broader audience. Although the disputants debate each other, the usually non-interactive and heterogeneous audience-which may consist of (a mix of) supporters, opponents and neutral bystanders-is in fact their primary addressee. ${ }^{9}$ In deliberation before an audience the procedural starting points are basically the same for all participants, but the material starting points are usually different in important respects. In their critical exchanges with each other all parties use argumentation to defend their standpoints in which they make use of each others' explicit and implicit (pre-eminently value-related) concessions and act in accordance with explicit or implicit procedural rules. The audience is usually heterogeneous and not interactive but the members of this audience determine nevertheless the outcome of the deliberation because they are the ones who decide in the end whether they (or some of them) have changed their mind or whether the initial situation will be maintained and in case it concerns a settlement they decide on how to vote.

There is room for strategic manoeuvring in all stages of the exchange and the conventional constraints on the manoeuvring are in the first place dictated by the institutional mission of the parties to reach their primary audience via a critical exchange with the secondary audience consisting of their actual interlocutors. In order not to seem non-cooperative, unresponsive, impolite or even rude to the primary audience, the participating parties have to take note of each others' questions, statements and other contributions and need to conduct their strategic manoeuvring accordingly. In addition, the format of the deliberation may impose still other constraints on the parties, like a chairman deciding on speaking turns, judging the relevance of contributions and allowing or not allowing interruptions. In all cases, whether it concerns parliamentary debate or other cases of public debate, the debaters have to conduct their strategic manoeuvring in accordance with the prevailing institutional preconditions.

The following example taken from the 2008 General Debate in Dutch Parliament, shows the Prime Minister, Mr. Balkenende, manoeuvring strategically by turning to the

\footnotetext{
${ }^{9}$ The audience may consist of listeners who are present on the occasion but also of people who are watching television, listening to the radio or reading the polemics in a newspaper.
} 


\section{IN VARIETATE CONCORDIA - UNITED IN DIVERSITY}

next point in order to escape from answering a question asked by a Member of Parliament (MP). In this case, Balkenende does not get away with his evasive manoeuvre because Dutch MPs have a right of information that entitles them to have all questions answered they regard necessary to judge the government's performance. After the MP whose question is ignored has protested, the Chair of the Second Chamber, Mrs. Verbeet, prevents Balkenende from carrying out this strategic manoeuvre by using her right as the Chair to intervene when a Member of Government denies an MP the information he requires. ${ }^{10}$

Prime Minister Balkenende:

"I will now start with the next part."

Mr. Rutte (Conservative Liberal Party):

"I thought you would also go into the asylum policy, but I did not get an answer to my question yet.”

Chair, Mrs. Verbeet:

"Part of the asylum policy has been addressed in an earlier stage of the debate, but not your question. [...] You are right.”

(Parliamentary Proceedings, 18 September 2008)

This fragment illustrates how in some respects the institutional preconditions for strategic manoeuvring may differ from communicative activity type to communicative activity type depending on the impact the need for realizing the institutional point of the communicative activity type and the ensuing goals and requirements of a particular genre of communicative activity have on the argumentative characteristics of the various stages of the argumentative process. The institutionalized macro-context of the General Debate in Dutch parliament puts certain conventional constraints on the strategic manoeuvring that is deemed acceptable in this activity type. Such general constraints can be determined for whole genres of communicative activity but within individual communicative activity types, due to specific requirements, some more specific constraints may apply.

As a consequence of these contextual peculiarities, in analyzing and evaluating argumentative discourse we need to take account not only of the dialectical and rhetorical aims intrinsic in strategic manoeuvring but also of the extrinsic constraints imposed on the manoeuvring by the institutional aims of the communicative activity type in which the argumentative discourse takes place. When taking our point of departure from the specific speech event we happen to examine, in the analysis and evaluation of argumentative discourse we turn, via the macro-context that determines in a certain communicative domain together with the genre of communicative activity that is used the institutional point of the communicative activity type, to the specific properties defining this communicative activity type as an argumentative activity type. In order to give a more precise account of the contextual constraints on strategic manoeuvring in activity types making use of $d$, we shall concentrate on the communicative activity type of

${ }^{10}$ According to Tonnard (in preparation), who examines in her forthcoming doctoral dissertation the various ways in which standpoints (and doubt) can be excluded from further consideration in Dutch parliamentary debate, Mrs. Verbeet supports the Members of Parliament in their pursuit for clear and relevant answers (www.tweedekamer.nl). 
plenary debate in European Parliament, because it is at the level of an individual activity type that the institutional preconditions for strategic manoeuvring manifest themselves most specifically.

\section{PLENARY DEBATE IN THE EUROPEAN PARLIAMENT}

Together with the Council of the European Union, consisting of government ministers from all the member states of the European Union (EU), the European Parliament decides on legislation and policies initiated and proposed by the European Commission, the politically independent institution representing and upholding the interests of the EU as a whole. Although the European Parliament blends a wide variety of national parliamentary traditions in its procedures, seating arrangements and style, it also has certain distinctive features of its own, owing to the various phases in which its powers in the European Union (EU) have evolved, the linguistic diversity it has to face and the specific treaty obligations it has to meet. Currently there are 785 Members of European Parliament (MEPs), drawn from the 27 member states of the enlarged Union; these MEPs represent over 140 different political parties, which are in the European Parliament organized in 7 Political Groups.

Initially, the powers of the European Parliament were limited to the right of veto. The implementation of the co-decision procedure for legislation, however, which was established under the Treaty of Maastricht and the Treaty of Amsterdam, substantially increased the political impact of the European Parliament and hence the importance of its debates. In areas where the co-decision procedure applies, the power is more or less equally divided between the Parliament and the Council. The co-decision procedure allows the European Parliament not only to veto legislation but also to amend it. At the same time, it locks the Parliament into a complex and intricate relationship with the Council, because a Commission proposal is presented to both the Parliament and the Council. If one reading does not lead to a decision, two more readings may follow.

In practice, the parliamentary work is organized through a system of standing and temporary committees that are responsible for the preparatory work for plenary parliamentary sittings. The committees draw up, adopt and amend legislative proposals as well as own-initiative reports, consider Commission and Council proposals and, where necessary, prepare reports to be presented to the plenary assembly. Much of their time the committees spend drawing up reports on legislation that is proposed by the Commission, but they can also draw up "own-initiative reports" on issues that fall within the scope of the committee's competence.

Through the Political Groups, Parliament represents the people of Europe. The Groups play a decisive role in choosing the President, Vice-Presidents and the committee chairs. They set the parliamentary agenda, choose the rapporteurs and decide on the allocation of speaking time (Corbett, Jacobs \& Shackleton 2007, p. 70-71). At present there are 7 Political Groups, which represent the political lines of thought prevalent in Europe, including the Eurosceptic movement, which is represented by the Independence/Democracy Group. Each Political Group consists of a great many national political parties. The Group of the European People's Party (Christian Democrats) and European Democrats (EPP-ED) is since 1999 the largest Group; since 2007 it has 277 members, which are distributed over 50 political parties. 


\section{IN VARIETATE CONCORDIA - UNITED IN DIVERSITY}

Political Groups issue voting instructions to their members, both about how to vote on texts and amendments and about which votes are particularly important. The position of a Group is defined not by instructions from above but by discussion and negotiation within the Group, involving the Group's coordinator in the relevant committee in the process. For a number of reasons Group "whipping” systems are less strict than in most national parliaments.11 First, in Europe there is no government demanding systematic support from its parliamentary majority. Second, on some issues it is hard to agree on a common group line because of the diversity of regional interests, national party interests and other interests represented within a Group. Third, there are fewer effective sanctions a Group can take against dissident members than most national parliaments can bring to bear (Corbett, Jacobs \& Shackleton 2007, p. 108). Nevertheless, Corbett, Jacobs and Shackleton observe, "most Groups can count on well over 80 per cent of their members supporting the Group line and this in turn means that it is the positions taken by Groups that are usually decisive in determining parliament's position” (2007, p. 108). However, if their own member state's interests are at stake, members may turn against Group decisions.

Debates in the European Parliament are generally not as lively and certainly not as interesting to the media as those conducted in national parliaments, even if the European Parliament has developed methods to enhance its members' role in actually shaping the policy outcomes rather than just rubberstamping them or serving simply as a forum (Corbett, Jacobs \& Shackleton 2007, p. 183).12 During the twelve plenary sessions held each year in Strasbourg and the six held in Brussels the President ensures that Parliament's Rules of Procedure are adhered to. Through his arbitration, the President guarantees that all activities of the institution and its constituent bodies run smoothly. Central to the organization of the debate is Rule 141 (Calling speakers and content of speeches):

(1) Members may not speak unless called upon to do so by the President. Members shall speak from their places and shall address the Chair; the President may invite them to come to the rostrum.

(2) If speakers depart from the subject, the President shall call them to order. A speaker who has already been called to order twice in the same debate may, on the third occasion, be forbidden by the President to speak for the remainder of the debate on the same subject.

(3) Without prejudice to his other disciplinary powers, the President may cause to be deleted from the reports of debates of sittings the speeches of members who have not been called upon to speak or who continue to speak beyond the time allotted to them.

(4) Speakers may not be interrupted except by the President. They may, however, by leave of the President, give way during their speech to allow another

\footnotetext{
${ }^{11}$ Some Political Groups have taken up the British tradition of issuing one-, two- or three-line whips (Corbett, Jacobs \& Shackleton 2007, p. 107).

${ }^{12}$ According to Corbett, Jacobs and Shackleton, the European Parliament "is not a very sexy Parliament in media terms. Compared to many national parliaments, it lacks the cut and thrust of debate between government and opposition. Like in the US Congress, its real work is done in committee. The plurality of languages used makes the debate far from spectacular" (2007, p. 9).
} 
member, the Commission or the Council to put a question to them on a particular point in their speech.

Plenary debate typically starts with an opening statement by the rapporteur of the committee that prepared the draft report or opinion for the relevant issue. Next the speakers contribute to the debate in the pre-designated order and in the designated time. The President closes the debate when all speakers on the list have had their say. Within a few days after the debate voting takes place.

There is relatively little regulation when it comes to individual contributions to the debate. The most important rules are that the speeches should be within the allocated speaking time and that the speaker should not depart from the subject. There are hardly any rules for order in the Chamber.13 In most debates each MEP taking part in the debate speaks only once and although the possibility to ask questions exists (Rule 141, part 4), interrupting a speaker is hardly customary. Each MEP is free to use the allocated speaking time freely and can therefore also react to earlier contributions to the debate. Responding later to criticism by other MEPs, however, is not possible. The general conclusion can be that in plenary European parliamentary debate there is all in all little room for direct interaction.

\section{PRELIMINARY OBSERVATIONS CONCERNING STRATEGIC MANEUVERING IN EUROPEAN PARLIAMENTARY DEBATE}

Debates held in the plenary sessions of European Parliament about the acceptability of legislative or non-legislative proposals prepared by the Committee or about the acceptability of amendments to proposals start from a report prepared by the relevant committee and presented by its rapporteur. Although the report may mention reasons for adopting a proposal, neither the committee nor its rapporteur should be seen as a party in the Chamber discussion. This is an important observation to start with.

In the initial situation of the debate that can be reconstructed as the confrontation stage a Member of Parliament puts forward a positive standpoint in which he expresses agreement to the proposal or a negative standpoint in which he expresses non-agreement. In addition, the MEP can also put forward a standpoint in which he expresses conditional agreement depending on whether one or more amendments will be adopted. Each speaker addresses via the President the parliament as a whole. Since we may take it that the Members of Parliament have no common opinion on the matter, there will be a difference of opinion between some of them that is in the simplest case non-mixed. If another Member of Parliament puts forward an opposing standpoint, this initiates a mixed difference of opinion between him and the first speaker. Then there is presumably also a non-mixed (if not mixed) difference of opinion between him and all or some of the other members of the audience in the Chamber.

The Rules of Procedure of the European Parliament provide explicitly the official procedural rules for the plenary debate that are part of the mutual agreement in the opening stage. The set-up of the debate is basically monological and the speaking time of the participants in the debate and the total duration of the debate are fixed in advance.

${ }^{13}$ The Onesta report from 2005 stated that the rules "shall in no way detract from the liveliness of parliamentary debates nor undermine Members' freedom of speech.” 


\section{IN VARIETATE CONCORDIA - UNITED IN DIVERSITY}

The speakers may take all legislation and motions that have been accepted earlier to be part of the material starting points of the debate. Because of the heterogeneous make-up of the European Parliament, the agreement on material starting points in the opening stage will in many other cases only be partial and cannot be presumed without any further verification.

There are no special constraints as to the argument schemes that can be employed in the argumentation stage. The types of argumentation used in European parliamentary debates will be largely determined by the fact that the debate is a political debate dealing with legislation and policy matters. Due to the monological set-up of the debate mentioned in our characterization of the opening stage, there is not much possibility for asking critical questions in reaction to argumentation advanced by fellow parliamentarians. In practice, parliamentarians can only respond to such critical questions by anticipating that they might rise. This means that in the normal course of events in European parliamentary debate the argumentation stage will not be passed through to the full.

Although plenary debates in European Parliament are always officially and explicitly closed by the President, there is no real concluding stage. Just like in national parliamentary debates the differences of opinion are not concluded by way of an intersubjective agreement on the outcome of the debate. The reason for this is that in such parliamentary debates one hardly ever sees the debaters come to agreement about the outcome of any of the (sub)discussions, if only because the value-related material starting points of the various (Groups of) MEPs are as a rule so different. The plenary parliamentary debates serve as a basis for justifying the casting of votes by the various (Groups of) MEPs in the voting that always concludes the decision-making process.

\begin{tabular}{|c|c|c|c|c|}
\hline \multicolumn{5}{|c|}{ Communicative activity type of a plenary debate in European Parliament } \\
\hline $\begin{array}{l}\text { genre of } \\
\text { communicative } \\
\text { activity }\end{array}$ & initial situation & $\begin{array}{l}\text { procedural and } \\
\text { material } \\
\text { starting points }\end{array}$ & $\begin{array}{l}\text { argumentative } \\
\text { means and } \\
\text { criticism }\end{array}$ & outcome \\
\hline deliberation & $\begin{array}{l}\text { disagreement } \\
\text { on policy issue } \\
\text { that is in } \\
\text { principle } \\
\text { mixed and } \\
\text { exceptionally } \\
\text { non-mixed; } \\
\text { decision } \\
\text { through a } \\
\text { settlement by } \\
\text { voting up to } \\
\text { the audience } \\
\text { consisting of } \\
\text { all MEPs }\end{array}$ & $\begin{array}{l}\text { explicitly } \\
\text { codified and } \\
\text { implicit rules } \\
\text { of debate; } \\
\text { explicit and } \\
\text { implicit } \\
\text { political } \\
\text { concessions by } \\
\text { (Groups of) } \\
\text { participants in } \\
\text { the debate }\end{array}$ & $\begin{array}{l}\text { argumentation } \\
\text { for or against } \\
\text { the proposal or } \\
\text { policy at issue } \\
\text { in response to } \\
\text { expressed or } \\
\text { anticipated } \\
\text { criticism in } \\
\text { exchanges } \\
\text { of speeches by } \\
\text { the participants } \\
\text { in the debate }\end{array}$ & $\begin{array}{l}\text { resolution of } \\
\text { disagreement } \\
\text { for parts of the } \\
\text { audience and } \\
\text { subsequent } \\
\text { settlement of } \\
\text { disagreement } \\
\text { by majority of } \\
\text { votes audience; } \\
\text { no return to } \\
\text { initial situation }\end{array}$ \\
\hline
\end{tabular}


Figure 3 Argumentative characterization of the communicative activity type of a plenary debate in European Parliament

Strategic manoeuvring in plenary debates in European Parliament is not only preconditioned by institutional regulations such as the debate format but by extension also by other factors pertinent to realizing the institutional point of this activity type such as the pursuit of the political goals of the Members of Parliament. Because the debate is conducted between MEPs belonging to different Political Groups and-at the current stage of European development also very important-having different national backgrounds, in analyzing the strategic manoeuvring that takes place these other factors must also be taken into account. Because it is unavoidable that MEPs in European Parliament not only promote the European cause but also try to serve the national interests of the countries they come from, when analyzing their strategic manoeuvring both the pursuit of the common cause and the pursuit of national causes must be considered.14 While European legislation is designed for the good of Europe as a whole, MEPs who feel (as may in particular easily happen when agriculture and industry are at issue) that their country will not really benefit from the new legislation or may even suffer from it may be inclined to promote views or propose amendments that combine serving the interests of the European Union with protecting their national interests in a better way.

In discussing European agricultural policy typical reactions to proposals that are made are the use of pragmatic argumentation or argumentation by example in which the MEP warns Parliament against the negative consequences the new legislative measures will have for his country. This happened, for instance, in a European parliamentary debate held on May 19, 2008 when a proposal was discussed to "continue deducting 5\% of the tobacco aid granted for the calendar years 2008 and 2009 and to use those funds to continue financing the Community Tobacco Fund, whose sole purpose is to finance information initiatives for improving European citizens' awareness of the harmful effects of tobacco consumption.” Diamanto Manolakou, a Greek MEP, reacted as follows:

Diamanto Manolakou, on behalf of the GUE/NGL Group. Madam President, tobacco growers are being cruelly persecuted, as the anti-smoking campaign is tantamount to an anti-tobacco policy. [...] Tobacco growing in Greece has declined by $73 \%$. Ever-increasing numbers of tobacco growers are unemployed. Whole areas are being abandoned because no alternative crops are grown there $[\ldots .$.$] .$

Manolakou refers in her argumentation to the negative consequences of the European tobacco policy for her own country. She presents her complaint strategically as a general one (tobacco growers are persecuted cruelly), but this general (and not specified) claim is backed up by an argument by example in which she refers only to Greece.

In a contribution to the same debate, the Polish MEP Janusz Wojciechowski tries to make it likely that the problems exceed the one country limits:

\footnotetext{
${ }^{14}$ When it is not immediately clear that a country's national interests are heavily affected by the proposed legislation or measure MEPs are generally inclined to take a political view on the matter and vote along political party lines.
} 


\title{
IN VARIETATE CONCORDIA - UNITED IN DIVERSITY
}

\begin{abstract}
Janusz Wojciechowski, on behalf of the UEN Group. Madam President, rarely do decisions debated in this House have such serious consequences for such a large number of people. The issue before us today is the existence or non-existence of tobacco producers in Europe. Tobacco production is the livelihood of around 120000 farmers and, including seasonal workers, it employs almost 400000 people in both old and new Member States. The case of Greece has already shown that the so-called reform of the tobacco sector in fact means its liquidation. It is a death sentence for 120000 farms, mostly small family holdings. I know such tobacco farms in Poland, but we find them here too, on the outskirts of Strasbourg [...].
\end{abstract}

By mentioning also the small family holdings on the outskirts of Strasbourg, Wojciechowki emphasizes the fact that the problem is not just a Polish or a Greek problem, but a general European one, that even exists very close to where Parliament meets. Both Manolakou and Wojciechowki make an effort to avoid giving the impression that the problems are only regional and that they are only arguing to protect the interests of their own country. They have to live up to the adage United in diversity.

Another mode of strategic manoeuvring used to reconcile serving the interests of the European Union with serving the different interests and views of the member states is emphasizing the coherence of the EU legislation. Because all members of the European Parliament may be expected to be in favour of a coherent legislation that does not contain any contradictions, the requirement of coherence can be seen as a common starting point. The coherence of European legislation and policy can be emphasized by means of different types of argumentation and the need for this coherence can be defended in different ways. A strategic manoeuvre that is based on the jointly recognized need for coherence is pointing out that taking a certain measure is contrary to European policyor, as the case may be, in line with European policy. In such a case the arguer points at an undesired consequence of adopting the proposal concerned, namely that European policy will no longer be coherent. In the debate about the tobacco subsidies we referred to earlier most MEPs opposing subsidies for the European tobacco growers emphasized in one way or other the resulting inconsistency of European policies. Here is an example provided by MEP Lily Jacobs:

Lily Jacobs (PSE). Tobacco kills about half a million European citizens a year. Even amongst nonsmokers there are 19000 deaths a year from passive smoking. How do I know that? That is the message in the television adverts the European Union itself is having shown in all 27 Member States as part of a big anti-smoking campaign. [...] Is it not very strange that we are trying to combat smoking and at the same time are funding tobacco production with European tax revenue? $[\ldots]$

Another MEP, Kartika Tamara Liotard, stresses in her contribution to the debate along a different line the importance of a non-contradictory EU policy. She claims that examples of incoherence have a negative effect on the public image of the European Union:

Kartika Tamara Liotard (GUE/NGL). It is difficult to say what is more absurd, that the European Union subsidies tobacco growing, or that Europe then uses part of the subsidies for a fund that discourages tobacco smoking. Totally hypocritical measures like that are precisely the reason why the EU has so little credibility with the public. [...]

These contributions to the debate on the issue of tobacco subsidies have in common that the arguers point at the negative consequence of incoherence in European policy resulting 


\section{FRANS H. VAN EEMEREN AND BART GARSSEN}

from accepting or rejecting a proposal. In so doing they employ symptomatic argumentation of a specific type. For the same purpose, however, they could just as well have made use of comparison argumentation in which similar legislation that has been accepted before is compared with the proposed legislation in order to increase or decrease the acceptability of this new legislation.

\section{CONCLUSION}

This exploration of plenary debate in the European Parliament has led to a definition of this debate as a specific argumentative activity type characterized by a particular initial situation, particular procedural and material starting points, particular argumentative means and criticism, and a particular kind of outcome. The institutional preconditions for strategic manoeuvring in argumentative discourse conducted in plenary debates in the European Parliament are determined by these characteristics, but also by the diverse national and political backgrounds of the European parliamentarians that play at this stage of European development an important part in how the parliamentarians try to achieve unity in diversity in actual argumentative practice. We have illustrated the predicament of the European Parliament by giving some examples of modes of strategic manoeuvring reflecting these preconditions. In this way we have introduced the new research project regarding strategic manoeuvring in European Parliament we are carrying out in collaboration with José Plug and Francisca Snoeck Henkemans.

Link to commentary

\section{REFERENCES}

Corbett, R., Jacobs, F., \& Schackleton, M. (2007). The European Parliament. London: John Harper Publishing.

Eemeren, F.H. van (to be published). Strategic Manoeuvring in Argumentative Discourse.

Eemeren, F. H. van, \& Houtlosser, P. (1999). William the Silent's argumentative discourse. In: F. H. van Eemeren, R. Grootendorst, J. A. Blair, \& Ch. A. Willard (Eds.), Proceedings of the Fourth Conference of the International Society for the Study of Argumentation (pp. 168-171). Amsterdam: Sic Sat.

Eemeren, F. H. van \& Houtlosser, P. (2000). The rhetoric of William the Silent's Apologie. A dialectical perspective. In: T. Suzuki, Y. Yano, \& T. Kato (Eds.), Proceedings of the $1^{\text {st }}$ Tokyo conference on argumentation (pp. 37-40). Tokyo: Japan Debate Association.

Eemeren, F. H. van \& Houtlosser, P. (2005). Theoretical construction and argumentative reality: an analytic model of critical discussion and conventionalised types of argumentative activity. In: D. Hitchcock \& D. Farr (Eds.), The Uses of Argument. Proceedings of a conference at McMaster University (pp. 75-84). Hamilton, ON: OSSA.

Eemeren, F. H. van, Houtlosser, P. Ihnen, C., \& Lewinski, M. (to be published). Contextual considerations in the Evaluation of Argumentation.

Hall, P. A. \& R. C. R. Taylor (1996). Political science and the three new institutionalisms. Political studies, 44, 936-957.

Ilie, C. (2003). Discourse and metadiscourse in parliamentary debates. Journal of language and Politics 2(1), 71-92.

Levinson, S. C. (1992). Activity types and language. In: P. Drew \& J. Heritage (Eds.), Talk at Work: Interaction in institutional settings, Cambridge: Cambridge University Press, Cambridge, 66-100.

March, J. G. \&, J. P. Olsen (1984). The new institutionalism: organizational factors in political life. The American Political Science Review, 78(3), 734-749. 


\section{IN VARIETATE CONCORDIA - UNITED IN DIVERSITY}

Walton, D. (1998). The New Dialectic: Conversational contexts of argument, University of Toronto Press, Toronto.

Walton, D. N., \& Krabbe, E. C. W. (1995). Commitment in Dialogue: Basic concepts of interpersonal reasoning. Albany, N.Y.: State University of New York Press.

Zarefsky, D. (2008). Strategic Maneuvring in Political Argumentation. Argumentation, 22(3), 317-330. 